\title{
EFFECTS OF GA 3 HORMONE TREATMENTS ON ION UPTAKE AND GROWTH OF PEPPER PLANTS UNDER CADMIUM STRESS
}

\author{
UZAL, O. ${ }^{*}$ - YASAR, F. \\ Van Yüzüncü Yll University, Agricultural Faculty, Horticulture Department, Van, Turkey \\ (phone: +90-505-487-8455/+90-532-511-9265; fax:+90-432-225-1104) \\ *Corresponding author \\ e-mail: ozlemuzal@yyu.edu.tr \\ (Received $13^{\text {th }}$ Jun 2017; accepted $4^{\text {th }}$ Sep 2017)
}

\begin{abstract}
The present study was conducted to identify the response of pepper plants under cadmium stress to gibberellic acid $\left(\mathrm{GA}_{3}\right)$ treatments. Plants were exposed to different cadmium chlorine doses $(0$, 20, 40, $60 \mathrm{ppm})$ cadmium chloride $\left(\mathrm{CdCl}_{2}\right)$ and $\mathrm{GA}_{3}(10 \mathrm{ppm})$ treatments. A resistance scale was used based on symptoms over the leaves and mineral element analyses $(\mathrm{K}, \mathrm{Cu}, \mathrm{Zn}, \mathrm{Fe}, \mathrm{Mn}, \mathrm{Mg}$ and $\mathrm{Cd})$ were performed. Experiments were conducted in hydroponic culture with Demre pepper cultivar under controlled conditions. Present results revealed significant effects of $\mathrm{Cd}$ treatments on $\mathrm{Cd}, \mathrm{Fe}, \mathrm{Zn}, \mathrm{Cu}, \mathrm{Mn}$, $\mathrm{Mg}$ and $\mathrm{K}$ concentrations of the plants. Combined treatments of $\mathrm{Cd}$ and $\mathrm{GA}_{3}(10 \mathrm{ppm})$ also increased ion accumulation especially in leaves. It was observed under stress conditions that $\mathrm{GA}_{3}$ hormone treatments inhibited plant growth to prevent stress, increased ion uptake, well-adjusted ion balance and let the plants avoid from stressors.
\end{abstract}

Keywords: cadmium, gibberellic acid, heavy metal stress, ion accumulation, pepper (Capsicum annuum L.)

\section{Introduction}

Industrialization and urbanization bring about serious environmental pollution and exert significant threats on nature (Güven et al., 1999).

Even the trace amounts of heavy metals in air, soil and water resources may be dangerous for all living things. Agricultural and industrial activities may significantly increase especially cadmium $(\mathrm{Cd})$ concentrations in the air surrounding us. The presence of heavy metals in trace amounts in soil, water and air can be dangerous to all living things, and the concentration of $\mathrm{Cd}$ in the environment is increasing due to agricultural and industrial factors (Foy et al., 1978). Such an increase is mostly resulted from anthropogenic sources and ultimately passed into the agricultural lands through sewage sludge treatments and fertilizer applications (Doğan and Saygideğer, 2009).

Cadmium may reduce germination, growth, development, yield and quality of various plants. Several studies were carried out to determine the threshold values and to investigate the morphological and physiological effects of Cd toxicity (Bertin and Averbeck, 2006).

Whether or not being essential element for plant growth, excessive heavy metal accumulation in plant tissues and organs negatively influence vegetative and generative organs of the plants (Gür et al., 2004). With toxic impacts, heavy metals may damage several physiological processes such as transpiration, stomatal conductance, enzyme activity, germination, protein synthesis, membrane stability and hormonal balance (Kennedy and Gonsalves, 1987). Toxicity may vary both from one metal to another and from one organism to another. Positive or negative (toxic) impacts not only depend on element type and concentration, but also closely related to genetic-based physiological responses of different species (Haktanır and Arcak, 1998). 
Cadmium stress reduces water and ion uptake of plants and hinders root growth and development. Stomata also close under cadmium stress, thus water loss through transpiration is reduced and cadmium transport is hindered (Salt et al., 1995). Cd accumulation may have toxic impacts on plants and damage mineral nutrition and carbohydrate metabolism of the plants, and then ultimately limits plants growth and development (John et al., 2009). Cadmium also inhibits chlorophyll biosynthesis and reduces total chlorophyll content (Stobart et al., 1985). Zinc and iron are essential micro nutrients for several biochemical processes in plants (Marschner, 1995). Cadmium interacts with these nutrients and directly influences nutrient uptake. Such interactions ultimately influence nutrient distribution, results in nutrient deficiency/imbalance and recesses plant growth and development (Zhang et al., 2002).

There is a consensus on stimulation of internal hormone levels through external application of different growth regulators (El-Shahaby et al., 1992). Rodriguez et al. (2006) indicated that the hormones in EP (extracellular products) produced by Cyanobacteria developed salt-tolerance in paddy seedlings. It was also indicated in the same study that GA treatments stimulated abscisic acid (ABA) production as a response to salt stress and altered and reduced the ratios of growth regulators.

The present study was conducted with pepper plants of Solanaceae family, mostly produced as early grown or summer plant in Turkey, to investigate: a) the effects of cadmium on metabolic activities of the plants; b) the response of plants and adaptation mechanisms developed against this pollutant; c) stress relief through gibberellic acid treatments; d) correlations of plant growth regulators with ion uptake and accumulation in plants.

\section{Materials and Methods}

Experiments for stress factors and plant growth were conducted in hydroponic culture in a climate cabin with a split air-conditioner to provide normal atmosphere.

Pepper seeds were sown in pumice-filled plastic germination containers $(40 \times 25 \times 5$ $\mathrm{cm})$. Following the sowing of 100 seeds to each container, irrigation was performed with tap-water. Containers had 9 holes $(0.5 \mathrm{~cm})$ beneath to drain the irrigation water. Pumice was thoroughly wetted and excess irrigation water was drained. Then germination containers were placed in climate cabin with $25^{\circ} \mathrm{C}$ temperature and $70 \%$ relative humidity. Containers were covered with moist paper and regularly controlled. Gradual tap water applications were continued to prevent the drying of pumice. Irrigations were started to be performed with Hoagland nutrient solution when the seedlings had horizontal cotyledon leaves and the first true leaves (Hoagland and Arnon, 1938). The seedlings with the $2^{\text {nd }}$ true leaves were transplanted into hydroponic culture. Plastic cuvettes $(25 \times 25 \times 18 \mathrm{~cm})$ filled with Hoagland nutrient solution were used for hydroponic culture. Pepper seedlings were wrapped around with small sponge pieces and placed in specially designed platforms with holes over for each seedling. These platforms were placed over the cuvettes as to have the roots immersed in nutrient solution. Aeration was supplied through the nutrient solution with thin plastic hoses connected to two aquarium pumps.

Following the growth of seedling in hydroponic culture for two weeks, cadmium treatments were initiated. Experiments were conducted by completely randomized design with three replications with 20 plants in each replication. For cadmium treatments, $0,20,40,60 \mathrm{ppm} \mathrm{CdCl}_{2}$ doses were added to nutrient solution $(1 / 2$ Hoagland). Solutions were renewed weekly and care was taken to sustain the same 
cadmium concentrations in each renewal. Together with cadmium, $10 \mathrm{ppm}$ gibberellic acid was applied to plants. Sampling for measurements and analyses were made 15 days after cadmium treatments. Samples were used to determine some plant growth parameters (green herbage fresh weight, number of leaves, plant heights, cadmium resistance scales based on leaf symptoms) and to determine some physico-chemical parameters ( $\mathrm{Cd}, \mathrm{K}, \mathrm{Cu}, \mathrm{Zn}, \mathrm{Fe}, \mathrm{Mn}, \mathrm{Mg}$ contents).

A total of 8 different treatments were performed (control, cadmium 20, 40, $60 \mathrm{ppm}$, cadmium 20, 40, $60 \mathrm{ppm}+$ gibberellic acid $\mathrm{GA}_{3}(10 \mathrm{ppm})$.

\section{Mineral element analysis}

Three leaves from tip to downward were taken and they were kept in deep freezer at $-40^{\circ} \mathrm{C}$. About $200 \mathrm{~g}$ samples were taken from the deep freezer and samples were supplemented with $10 \mathrm{ml} 0.1 \mathrm{~N} \mathrm{HNO}_{3}$ (Nitric acid). They were then kept in plastic boxes at dark and room temperature for a week. Samples were shaken in a shaker for 24 hours and resultant extract was subjected to $\mathrm{K}^{+}, \mathrm{Cu}^{+}, \mathrm{Zn}^{+}, \mathrm{Fe}^{+}, \mathrm{Mn}^{+}, \mathrm{Mg}^{+}, \mathrm{Cd}$ ion analyses in flame photometer (Eppendorf flame photometer). Fresh leaf ion concentrations were expressed in $\mu \mathrm{g} / \mathrm{mg}$ fresh weight (Taleisnik et al., 1997).

Experiments were conducted in randomized plots design with 3 replications. Statistical analyses for plant growth parameters, ion and enzyme data were performed with SAS (1985) software.

\section{Results}

Data about plant growth parameters are provided in Table 1. While the greatest root weight was obtained from the control treatment, the lowest value was obtained from $\mathrm{Cd} 3+\mathrm{GA}_{3}$ treatment. The same treatments had the similar characteristics for root lengths. Control treatment had the greatest stem weight and it was followed by $\mathrm{GA}_{3}$ treatment. As compared to the control treatment, the greatest decrease was observed in $\mathrm{Cd}+\mathrm{GA}_{3}$ treatment, but it was placed in the same statistical group.

Table 1. Plant growth and development parameters

\begin{tabular}{|c|c|c|c|c|c|c|c|}
\hline Applications & $\begin{array}{l}\text { Root } \\
\text { weight }\end{array}$ & $\begin{array}{l}\text { Root } \\
\text { height }\end{array}$ & $\begin{array}{l}\text { Stem } \\
\text { weight }\end{array}$ & $\begin{array}{l}\text { Stem } \\
\text { height }\end{array}$ & $\begin{array}{l}\text { Leaf } \\
\text { weight }\end{array}$ & $\begin{array}{l}\text { Number } \\
\text { of leaves }\end{array}$ & $\begin{array}{c}\text { Total } \\
\text { plant } \\
\text { weight }\end{array}$ \\
\hline & (g) & $(\mathrm{cm})$ & (g) & $(\mathrm{cm})$ & (g) & (number) & (g) \\
\hline Control & $2.303 \mathrm{~A}$ & $19.833 \mathrm{~A}$ & $1.778 \mathrm{~A}$ & $11.833 \mathrm{~A}$ & $6.670 \mathrm{~A}$ & $9.500 \mathrm{~A}$ & $10.751 \mathrm{~A}$ \\
\hline $\mathrm{Cd} 1+\mathrm{GA}_{3}$ & $1.220 \mathrm{C}$ & $\begin{array}{l}10.550 \\
C D\end{array}$ & $0.790 \mathrm{C}$ & $10.500 \mathrm{~A}$ & $2.930 \mathrm{D}$ & $7.000 \mathrm{C}$ & $4.940 \mathrm{EF}$ \\
\hline $\mathrm{Cd} 2+\mathrm{GA}_{3}$ & $1.991 \mathrm{AB}$ & $\begin{array}{l}14.167 \\
\mathrm{BC}\end{array}$ & $0.713 \mathrm{C}$ & $9.667 \mathrm{~A}$ & $2.571 \mathrm{DE}$ & $6.833 \mathrm{C}$ & $5.275 \mathrm{DE}$ \\
\hline $\mathrm{Cd} 3+\mathrm{GA}_{3}$ & $1.075 \mathrm{C}$ & $9.333 \mathrm{D}$ & $0.615 \mathrm{C}$ & $10.167 \mathrm{~A}$ & $1.900 \mathrm{E}$ & $6.000 \mathrm{C}$ & $3.590 \mathrm{~F}$ \\
\hline $\mathrm{Cd} 1$ & $1.348 \mathrm{BC}$ & $\begin{array}{l}15.833 \\
\mathrm{AB}\end{array}$ & $1.365 \mathrm{AB}$ & $11.000 \mathrm{~A}$ & $4.483 \mathrm{C}$ & $7.333 \mathrm{BC}$ & $7.196 \mathrm{C}$ \\
\hline $\mathrm{Cd} 2$ & $1.510 \mathrm{BC}$ & $\begin{array}{l}16.833 \\
\mathrm{AB}\end{array}$ & $1.323 \mathrm{~B}$ & $11.000 \mathrm{~A}$ & $3.733 \mathrm{C}$ & $7.333 \mathrm{BC}$ & $6.743 \mathrm{CD}$ \\
\hline $\mathrm{Cd} 3$ & $1.298 \mathrm{C}$ & $\begin{array}{l}16.667 \\
\mathrm{AB}\end{array}$ & $1.311 \mathrm{~B}$ & $10.167 \mathrm{~A}$ & $2.898 \mathrm{D}$ & $7.066 \mathrm{C}$ & $6.908 \mathrm{CD}$ \\
\hline $\mathrm{GA}_{3}$ & $\begin{array}{l}1.686 \text { A- } \\
\mathrm{C}\end{array}$ & $\begin{array}{l}14.167 \\
\mathrm{BC}\end{array}$ & $1.725 \mathrm{~A}$ & $11.667 \mathrm{~A}$ & $5.686 \mathrm{~B}$ & $9.166 \mathrm{AB}$ & $9.097 \mathrm{~B}$ \\
\hline
\end{tabular}

Means indicated with the same letters in the same column are not significantly different. 
There were not any significant differences in stem lengths of the treatments. Control treatment had the greatest leaf weight. As compared to the control treatment, the greatest decrease was observed in $\mathrm{Cd} 3+\mathrm{GA}_{3}$ treatment. The results for number of leaves were similar with the results for leaf weight. The greatest plant weight was observed in control treatment and the greatest decrease as compared to control treatment was observed in $\mathrm{Cd} 3+\mathrm{GA}_{3}$ treatment. With regard to all growth parameters, it is remarkable that the lowest values were seen in $\mathrm{Cd} 3+\mathrm{GA}_{3}$ treatment. Again as compared to the control treatment, leaf weight, number of leaves, total plant weight decreased with increasing cadmium doses.

As compared to control and single $\mathrm{Cd}$ treatments, $\mathrm{Cd}+\mathrm{GA}_{3}$ treatments increased root, stem and leaf $\mathrm{Cd}$ concentrations. The greatest leaf $\mathrm{Cd}$ accumulation in single $\mathrm{Cd}$ treatments was observed in leaves (Table 2). The greatest root cadmium concentrations were observed in $\mathrm{Cd} 3+\mathrm{GA}_{3}, \mathrm{Cd} 2+\mathrm{GA}_{3}$ treatments and they were followed by $\mathrm{Cd} 1+$ $\mathrm{GA}_{3}$ treatment. The greatest stem cadmium concentration was observed in $\mathrm{Cd} 3+\mathrm{GA}_{3}$ treatment and it was followed by $\mathrm{Cd} 2+\mathrm{GA}_{3}$ and $\mathrm{Cd} 1+\mathrm{GA}_{3}$ treatments. The greatest root and stem cadmium concentrations were observed in $\mathrm{Cd} 3+\mathrm{GA}_{3}$ treatments and increasing values were observed with increasing treatment doses. The same case was not valid for leaves; the greatest leaf cadmium concentration was obtained from $\mathrm{Cd} 3$ treatment and it was followed by $\mathrm{Cd} 2$ and $\mathrm{Cd} 1$ treatments.

Table 2. Root, stem and leaf Cd concentrations ( $\mu \mathrm{g} / \mathrm{mg}$ T.A.)

\begin{tabular}{llll}
\hline APPLICATIONS & ROOT & STEM & LEAF \\
\hline & Cd & Cd & Cd \\
\hline Control & $1.17 \mathrm{D}$ & $0.786 \mathrm{E}$ & $0.629 \mathrm{E}$ \\
$\mathrm{Cd} 1+\mathrm{GA}_{3}$ & $592.32 \mathrm{~B}$ & $20.678 \mathrm{~B}$ & $8.183 \mathrm{D}$ \\
$\mathrm{Cd} 2+\mathrm{GA}_{3}$ & $737.52 \mathrm{~A}$ & $21.895 \mathrm{~B}$ & $19.896 \mathrm{C}$ \\
$\mathrm{Cd} 3+\mathrm{GA}_{3}$ & $748.40 \mathrm{~A}$ & $27.500 \mathrm{~A}$ & $20.759 \mathrm{C}$ \\
$\mathrm{Cd} 1$ & $438.16 \mathrm{C}$ & $5.373 \mathrm{D}$ & $27.895 \mathrm{~B}$ \\
$\mathrm{Cd} 2$ & $468.75 \mathrm{C}$ & $9.718 \mathrm{C}$ & $31.284 \mathrm{AB}$ \\
$\mathrm{Cd} 3$ & $488.08 \mathrm{C}$ & $12.152 \mathrm{C}$ & $34.463 \mathrm{~A}$ \\
$\mathrm{GA}_{3}$ & $1.14 \mathrm{D}$ & $0.505 \mathrm{E}$ & $0.447 \mathrm{E}$ \\
\hline
\end{tabular}

Means indicated with the same letters in the same column are not significantly different.

There were remarkable differences in $\mathrm{Fe}$ contents of plant organs in different treatments (Table 3). While the greatest root Fe content was obtained from the control treatment, the greatest stem $\mathrm{Fe}$ content was obtained from $\mathrm{GA}_{3}$ treatment and the greatest leaf Fe content was obtained from the control and $\mathrm{GA}_{3}$ treatments. The lowest root and stem $\mathrm{Fe}$ contents were obtained from $\mathrm{Cd} 3+\mathrm{GA}_{3}$ treatment and the lowest leaf $\mathrm{Fe}$ content was obtained from Cd1 treatment.

Considering the $\mathrm{Zn}$ contents of the roots, stems and leaves of treated plants, the greatest values were obtained from the control and $\mathrm{GA}_{3}$ treatments and the lowest values were obtained from single $\mathrm{Cd}$ treatments. As compared to control and single $\mathrm{GA}_{3}$ treatments, $\mathrm{Zn}$ contents decreased with $\mathrm{Cd}+\mathrm{GA}_{3}$ treatments, but increased with single Cd treatments (Table 4). 
Table 3. Root, stem and leaf Fe concentrations ( $\mu \mathrm{g} / \mathrm{mg}$ T.A.)

\begin{tabular}{llcl}
\hline APPLICATIONS & ROOT & STEM & LEAF \\
\hline & $\mathrm{Fe}$ & $\mathrm{Fe}$ & $\mathrm{Fe}$ \\
\hline Control & $2007.17 \mathrm{~A}$ & $67.868 \mathrm{C}$ & $117.069 \mathrm{~A}$ \\
$\mathrm{Cd} 1+\mathrm{GA}_{3}$ & $1975.02 \mathrm{AB}$ & $70.118 \mathrm{C}$ & $83.241 \mathrm{~B}$ \\
$\mathrm{Cd} 2+\mathrm{GA}_{3}$ & $1732.66 \mathrm{C}$ & $52.837 \mathrm{D}$ & $83.141 \mathrm{~B}$ \\
$\mathrm{Cd} 3+\mathrm{GA}_{3}$ & $1234.88 \mathrm{E}$ & $37.097 \mathrm{E}$ & $51.767 \mathrm{D}$ \\
$\mathrm{Cd} 1$ & $1456.66 \mathrm{D}$ & $31.742 \mathrm{E}$ & $35.582 \mathrm{E}$ \\
$\mathrm{Cd} 2$ & $1535.60 \mathrm{D}$ & $31.872 \mathrm{E}$ & $47.357 \mathrm{D}$ \\
$\mathrm{Cd} 3$ & $1728.47 \mathrm{C}$ & $37.438 \mathrm{E}$ & $60.662 \mathrm{C}$ \\
$\mathrm{GA}_{3}$ & $1815.32 \mathrm{BC}$ & $92.548 \mathrm{~A}$ & $123.345 \mathrm{~A}$ \\
\hline
\end{tabular}

Means indicated with the same letters in the same column are not significantly different.

Table 4. Root, stem and leaf Zn concentrations ( $\mu \mathrm{g} / \mathrm{mg}$ T.A.)

\begin{tabular}{llll}
\hline APPLICATIONS & ROOT & STEM & LEAF \\
\hline & $\mathrm{Zn}$ & $\mathrm{Zn}$ & $\mathrm{Zn}$ \\
\hline Control & $55.601 \mathrm{~A}$ & $9.5197 \mathrm{~A}$ & $9.6410 \mathrm{BC}$ \\
$\mathrm{Cd} 1+\mathrm{GA}_{3}$ & $50.569 \mathrm{AB}$ & $8.5043 \mathrm{~B}$ & $8.3917 \mathrm{BC}$ \\
$\mathrm{Cd} 2+\mathrm{GA}_{3}$ & $50.833 \mathrm{AB}$ & $8.9163 \mathrm{AB}$ & $8.7853 \mathrm{BC}$ \\
$\mathrm{Cd} 3+\mathrm{GA}_{3}$ & $48.915 \mathrm{AB}$ & $7.0087 \mathrm{C}$ & $8.3247 \mathrm{BC}$ \\
$\mathrm{Cd} 1$ & $33.755 \mathrm{DE}$ & $4.6890 \mathrm{D}$ & $5.9730 \mathrm{D}$ \\
$\mathrm{Cd} 2$ & $39.789 \mathrm{CD}$ & $4.2420 \mathrm{D}$ & $5.9220 \mathrm{D}$ \\
$\mathrm{Cd} 3$ & $35.123 \mathrm{DE}$ & $4.9230 \mathrm{D}$ & $5.7107 \mathrm{D}$ \\
$\mathrm{GA}_{3}$ & $56.944 \mathrm{~A}$ & $9.7750 \mathrm{~A}$ & $9.2063 \mathrm{AB}$ \\
\hline
\end{tabular}

Means indicated with the same letters in the same column are not significantly different.

With regard to $\mathrm{Cu}$ accumulation in roots, stems and leaves of pepper plants, similar with $\mathrm{Fe}$ and $\mathrm{Zn}$, the greatest values were observed in control and $\mathrm{GA}_{3}$ treatments without $\mathrm{Cd}$ treatments. As compared to control treatment, decrease was observed with $\mathrm{Cd}+\mathrm{GA}_{3}$ treatments; however $\mathrm{Cu}$ accumulation levels were lower in single $\mathrm{Cd}$ treatments (Table 5).

Considering $\mathrm{Mn}$ accumulation in roots, stems and leaves of pepper plants, the greatest values were observed in control and $\mathrm{GA}_{3}$ treatments. As compared to control treatment, $\mathrm{Cd}+$ $\mathrm{GA}_{3}$ treatments generally decreased $\mathrm{Mn}$ contents of roots and leaves, but yielded higher $\mathrm{Mn}$ contents than single $\mathrm{Cd}$ treatments. $\mathrm{Cd}+\mathrm{GA}_{3}$ treatments yielded the same stem Mn contents with the control treatment, but higher than Cd treatments (Table 6).

Table 5. Root, stem and leaf Cu concentrations ( $\mu$ g/mg T.A.)

\begin{tabular}{llll}
\hline APPLICATIONS & ROOT & STEM & LEAF \\
\hline & $\mathrm{Cu}$ & $\mathrm{Cu}$ & $\mathrm{Cu}$ \\
\hline Control & $13.379 \mathrm{~A}$ & $3.6810 \mathrm{~A}$ & $3.8047 \mathrm{~A}$ \\
$\mathrm{Cd} 1+\mathrm{GA}_{3}$ & $10.021 \mathrm{BC}$ & $1.8233 \mathrm{CD}$ & $3.0947 \mathrm{AB}$ \\
$\mathrm{Cd} 2+\mathrm{GA}_{3}$ & $11.060 \mathrm{~B}$ & $2.3680 \mathrm{BC}$ & $2.6833 \mathrm{~B}$ \\
$\mathrm{Cd} 3+\mathrm{GA}_{3}$ & $9.781 \mathrm{BC}$ & $2.8907 \mathrm{~B}$ & $2.7610 \mathrm{~B}$ \\
$\mathrm{Cd} 1$ & $8.319 \mathrm{C}$ & $1.4003 \mathrm{DE}$ & $2.7590 \mathrm{~B}$ \\
$\mathrm{Cd} 2$ & $8.962 \mathrm{BC}$ & $1.1940 \mathrm{E}$ & $2.3107 \mathrm{C}$ \\
$\mathrm{Cd} 3$ & $8.660 \mathrm{BC}$ & $1.6737 \mathrm{DE}$ & $2.1593 \mathrm{C}$ \\
$\mathrm{GA}_{3}$ & $12.549 \mathrm{~A}$ & $3.7523 \mathrm{~A}$ & $3.7723 \mathrm{~A}$ \\
\hline
\end{tabular}

Means indicated with the same letters in the same column are not significantly different. 
Table 6. Root, stem and leaf Mn concentrations ( $\mu \mathrm{g} / \mathrm{mg}$ T.A.)

\begin{tabular}{llll}
\hline APPLICATIONS & ROOT & STEM & LEAF \\
\hline & Mn & Mn & Mn \\
\hline Control & $265.12 \mathrm{~A}$ & $10.4447 \mathrm{~A}$ & $25.054 \mathrm{~A}$ \\
$\mathrm{Cd} 1+\mathrm{GA}_{3}$ & $180.62 \mathrm{BC}$ & $10.7663 \mathrm{~A}$ & $22.349 \mathrm{~B}$ \\
$\mathrm{Cd} 2+\mathrm{GA}_{3}$ & $256.66 \mathrm{~A}$ & $10.3053 \mathrm{~A}$ & $23.168 \mathrm{~B}$ \\
$\mathrm{Cd} 3+\mathrm{GA}_{3}$ & $202.31 \mathrm{~B}$ & $10.3833 \mathrm{~A}$ & $22.392 \mathrm{~B}$ \\
$\mathrm{Cd} 1$ & $98.69 \mathrm{D}$ & $5.8190 \mathrm{~B}$ & $11.960 \mathrm{D}$ \\
$\mathrm{Cd} 2$ & $109.17 \mathrm{D}$ & $6.8473 \mathrm{~B}$ & $11.721 \mathrm{D}$ \\
$\mathrm{Cd} 3$ & $98.34 \mathrm{D}$ & $6.8153 \mathrm{~B}$ & $15.042 \mathrm{C}$ \\
$\mathrm{GA}_{3}$ & $243.89 \mathrm{~A}$ & $10.8620 \mathrm{~A}$ & $27.505 \mathrm{~A}$ \\
\hline
\end{tabular}

Means indicated with the same letters in the same column are not significantly different.

Control treatments had the greatest root $\mathrm{Mg}$ contents. However, contrary to other ion concentrations, single $\mathrm{GA}_{3}$ treatments had the least $\mathrm{Mg}$ accumulation levels. $\mathrm{Cd}+\mathrm{GA}_{3}$ treatments also had lower $\mathrm{Cd}$ accumulations than single $\mathrm{Cd}$ treatments. With regard to stem $\mathrm{Mg}$ contents, $\mathrm{Cd}+\mathrm{GA}_{3}$ treatments were placed in the same statistical group with control treatments, but single $\mathrm{Cd}$ treatments had lower stem $\mathrm{Cd}$ contents and were places in different statistical group. As it was in other ions, the differences in root, stem and leaf $\mathrm{Mg}$ contents of different cadmium doses were not found to be significant (Table 7).

Table 7. Root, stem and leaf Mg concentrations ( $\mu \mathrm{g} / \mathrm{mg}$ T.A.)

\begin{tabular}{llll}
\hline APPLICATIONS & ROOT & STEM & LEAF \\
\hline & $\mathrm{Mg}$ & $\mathrm{Mg}$ & $\mathrm{Mg}$ \\
\hline Control & $61.354 \mathrm{~A}$ & $30.467 \mathrm{~A}$ & $27.889 \mathrm{~A}$ \\
$\mathrm{Cd} 1+\mathrm{GA}_{3}$ & $24.376 \mathrm{CD}$ & $29.546 \mathrm{AB}$ & $29.322 \mathrm{~A}$ \\
$\mathrm{Cd} 2+\mathrm{GA}_{3}$ & $22.798 \mathrm{D}$ & $30.160 \mathrm{AB}$ & $27.485 \mathrm{~A}$ \\
$\mathrm{Cd} 3+\mathrm{GA}_{3}$ & $23.237 \mathrm{D}$ & $26.924 \mathrm{~B}$ & $23.255 \mathrm{~B}$ \\
$\mathrm{Cd} 1$ & $38.136 \mathrm{~B}$ & $13.390 \mathrm{D}$ & $21.836 \mathrm{~B}$ \\
$\mathrm{Cd} 2$ & $31.969 \mathrm{BC}$ & $17.091 \mathrm{C}$ & $22.644 \mathrm{~B}$ \\
$\mathrm{Cd} 3$ & $29.839 \mathrm{BC}$ & $16.864 \mathrm{C}$ & $23.536 \mathrm{~B}$ \\
$\mathrm{GA}_{3}$ & $19.182 \mathrm{D}$ & $29.389 \mathrm{AB}$ & $28.706 \mathrm{~A}$ \\
\hline
\end{tabular}

Means indicated with the same letters in the same column are not significantly different.

Table 8. Root, stem and leaf $K$ concentrations ( $\mu \mathrm{g} / \mathrm{mg}$ T.A.)

\begin{tabular}{lccl}
\hline APPLICATIONS & ROOT & STEM & \multicolumn{1}{c}{ LEAF } \\
\hline \multicolumn{1}{c}{$\mathrm{K}^{+}$} & $\mathrm{K}^{+}$ & $\mathrm{K}^{+}$ \\
\hline Control & $306.82 \mathrm{~A}$ & $339.97 \mathrm{~A}$ & $317.73 \mathrm{~A}$ \\
$\mathrm{Cd} 2+\mathrm{GA}_{3}$ & $157.68 \mathrm{~B}$ & $327.60 \mathrm{~A}$ & $284.20 \mathrm{AB}$ \\
$\mathrm{Cd} 3+\mathrm{GA}_{3}$ & $164.41 \mathrm{~B}$ & $334.99 \mathrm{~A}$ & $278.43 \mathrm{AB}$ \\
$\mathrm{Cd} 1$ & $158.21 \mathrm{~B}$ & $325.24 \mathrm{~A}$ & $278.09 \mathrm{AB}$ \\
$\mathrm{Cd} 2$ & $126.95 \mathrm{CD}$ & $230.64 \mathrm{~B}$ & $259.45 \mathrm{BC}$ \\
$\mathrm{Cd} 3$ & $134.78 \mathrm{C}-\mathrm{D}$ & $224.87 \mathrm{~B}$ & $214.04 \mathrm{C}$ \\
$\mathrm{GA}_{3}$ & $132.69 \mathrm{C}-\mathrm{D}$ & $239.86 \mathrm{~B}$ & $216.80 \mathrm{C}$ \\
\hline
\end{tabular}

Means indicated with the same letters in the same column are not significantly different. 
Potassium $(\mathrm{K})$ contents of root, stem and leaf samples are provided in Table 8. The greatest root $\mathrm{K}$ content was obtained from the control treatment and it was respectively followed by $\mathrm{Cd}+\mathrm{GA}_{3}$ treatments and single $\mathrm{GA}_{3}$ treatment. The least root $\mathrm{K}$ content was obtained from single $\mathrm{Cd}$ treatments, but the differences between $\mathrm{Cd}$ doses were not significant. The differences in stem and leaf $\mathrm{K}$ contents of different $\mathrm{Cd}$ doses were not also found to be significant. Only the differences between $\mathrm{Cd}$ and $\mathrm{GA}_{3}$ treatments were found to be significant.

\section{Discussion}

Current findings revealed that cadmium significantly hindered root, stem and leaf growth of pepper seedlings. However, differences in plant growth parameters of different cadmium doses were not found to be significant. Despite the insignificant differences in stem lengths, $\mathrm{Cd}+\mathrm{GA}_{3}$ treatments inhibited plant growth and development. Current findings about the effects of cadmium comply with results of various earlier studies carried out with different plants. It was previously reported that cadmium inhibited root and stem growth of Vigna unguiculata L. var. Pusa falguni plants (Nagor, 1997); cadmium, copper, lead and zinc reduced root and shoot development of Sorghum bicolour L. plants (Pandit and Prasannakumar, 1999). Cadmium and nickel reduced root and stem lengths of Oryza sativa L. cv. Bahia plants (Moya et al., 1993); zinc reduced stem lengths of Brassica juncea seedlings (Prasad et al., 1999); cadmium also reduced stem and root lengths of Zea mays L. Dekalp cv. 73 Sponsor plants (Rascio et al., 1993). Similarly, Zengin and Munzuroğlu (2003) investigated the effects of cadmium $\left(\mathrm{CdCl}_{2} \cdot \mathrm{H}_{2} \mathrm{O}\right)$ on root, stem and leaf growth of bean seedlings and reported that cadmium significantly hindered root, stem and leaf growth and inhibitions were parallel to increasing cadmium doses. As compared to control treatment, plant growth was slow in $\mathrm{Cd}+\mathrm{GA}_{3}$ treatments. Yasar et al. (2016) applied $\mathrm{GA}_{3}$ to eggplant seedlings under salt stress and reported selective ion uptake of plants. As reported by Ashraf et al (2001), GA 3 might have reduced nitrogen uptake of the plants. Combined application of $\mathrm{GA}_{3}$ and cytokine-like growth regulators may provide positive contribution in elimination of salt stress (Xiong et al., 2002). Lin and Kao (1995) and Rodriguez et al. (2006) also reported that $\mathrm{GA}_{3}$ treatments reduced the growth inhibition of paddy and some other plants.

$\mathrm{Cd}$ treatments increased root, stem and leaf $\mathrm{Cd}$ concentrations as compared to control and single $\mathrm{GA}_{3}$ treatments. Cd accumulation in roots and stems were higher in $\mathrm{Cd}+\mathrm{GA}_{3}$ treatments than in single Cd treatments. However, an inverse case was valid for leaves. It was observed that $\mathrm{GA}_{3}$ prevented toxic ion transport to leaves to prevent heavy metal toxicity. Several researchers reported increasing plant $\mathrm{Cd}$ concentrations with increasing Cd doses. Bachir et al. (2004) reported increasing plant $\mathrm{Cd}$ concentrations with Cd treatments in cotton; Safarzadeh et al. (2013) reported the same case in paddy plants. Tiryakioğlu et al. (2006) reported that increasing $\mathrm{Cd}$ doses increased green herbage and especially root $\mathrm{Cd}$ concentrations, majority of cadmium taken up by the plants accumulated in roots and slight amounts were transported to green herbage.

Cadmium treatments significantly reduced $\mathrm{Fe}, \mathrm{Zn}$ and $\mathrm{Cu}$ concentrations of all plant organs. However, as compared to single $\mathrm{Cd}$ treatments, $\mathrm{Cd}+\mathrm{GA}_{3}$ treatments increased $\mathrm{Fe}, \mathrm{Zn}$ and $\mathrm{Cu}$ accumulations in all three plant organs. Single $\mathrm{GA}_{3}$ treatments also increased stem and especially leaf $\mathrm{Fe}, \mathrm{Zn}$ and $\mathrm{Cu}$ accumulations as 
compared to single Cd treatments. Similarly, Bachir et al. (2004) reported that 0.1 and $1 \mu \mathrm{M} \mathrm{Cd}$ treatments increased $\mathrm{Fe}, \mathrm{Zn}$ and $\mathrm{Cu}$ concentrations of cotton plants and indicated a potential synergic effect of $\mathrm{Cd}$ on Fe and $\mathrm{Zn}$ uptake. Köleli et al. (2004) reported under $\mathrm{Zn}$-deficient conditions that increasing $\mathrm{Cd}$ treatments reduced green herbage Fe concentrations; however, $\mathrm{Cd}$ treatments did not have significant effects on green herbage Fe concentrations under Zn-sufficient conditions. Safarzadeh et al. (2013) also reported that $\mathrm{Cd}$ treatments significantly reduced green herbage $\mathrm{Zn}$ and Fe concentrations. Wu et al. (2004) carried out a study about the effects of cadmium on micro element uptake and transport in cotton plants and reported that $0,0.1$ and 1 $\mu \mathrm{M} \mathrm{Cd}$ treatments did not change leaf $\mathrm{Fe}, \mathrm{Zn}$ and $\mathrm{Cu}$ concentrations significantly, but $10 \mu \mathrm{M} \mathrm{Cd}$ treatment significantly increased leaf micro element concentrations. Amal et al. (2014) applied $\mathrm{GA}_{3}$ to barley plants under salt stress and reported decreasing $\mathrm{Zn}, \mathrm{Fe}, \mathrm{Co}, \mathrm{Pb}, \mathrm{Cr}, \mathrm{Cd}$ and $\mathrm{Mn}$ ion accumulation under salt stress and indicated that $\mathrm{GA}_{3}$ treatments relieved the impacts of salt stress and increased ion uptake levels. Akman (2009) also reported similar results for $\mathrm{Fe}, \mathrm{Zn}$ and $\mathrm{Cu}$ ion accumulation in wheat.

As it was in other ion accumulations, $\mathrm{Cd}$ and $\mathrm{GA}_{3}$ treatments yielded similar results for $\mathrm{K}, \mathrm{Mn}$ and $\mathrm{Mg}$ accumulations. Cd treatments reduced the accumulation levels of all ions, except for $\mathrm{Cd} ; \mathrm{GA}_{3}$ treatments also yielded slight decreases in accumulation of all ions again except for $\mathrm{Cd}$ as compared to control treatment, but increased ion accumulation as compared to single Cd treatments. Mohamed and Gomaa (2012) and Amal et al. (2014) carried out a study with barley plants under salt stress and reported that $\mathrm{GA}_{3}$ treatments reduced $\mathrm{K}, \mathrm{Mn}$ and $\mathrm{Mg}$ ion accumulation levels in plants and $\mathrm{GA}_{3}$ treatments also reduced the impacts of salt stress and increased ion uptakes. Similarly, Schachtman and Lio (1999) in barley and Iqbal and Ashraf (2013) in wheat plants under salt stress, reported that salt stress reduced ion uptake in $\mathrm{GA}_{3}$ treatments, but $\mathrm{GA}_{3}$ treatments improved ion uptake of plants under salt stress.

It was concluded based on current findings that combined $\mathrm{GA}_{3}$ and $\mathrm{Cd}$ treatments did not have positive contributions to plant growth, but plant under these treatments behaved selectively in ion uptakes to prevent from toxic impacts of Cd. Such impacts of growth regulation hormone GA were also reported by previous researchers. When applied to plants under abiotic stressors, GA inhibited plant growth through synthesis of DELLA proteins. GA treatments increase the activity of this protein and may have positive contributions to stress tolerance of the plants since it inhibits plant growth under abiotic stress conditions (Achard et al., 2006; Achard et al., 2008a; Magome et al., 2008). Increased DELLA activity with GA treatments limits the accumulation of reactive oxygen species (ROS) under Cd stress, thus prevents cell deaths (Achard et al., 2008b). DELLA proteins were reported as behaved like inner-cell suppressors of GAinduced metabolic activities (Peng et al., 1997; Silverstone et al., 1998; Ogawa et al., 2000; Ikeda et al., 2001; Chandler et al., 2002).

\section{Conclusion}

When we evaluate the data we obtained without working, we found that the $\mathrm{GA}_{3}$ application increased ion uptake in plants, $\mathrm{GA}_{3}$ treatment with $\mathrm{Cd}$ inhibited plant growth, but $\mathrm{Cd}$ and $\mathrm{GA}_{3}$ treatments did not cause damage to plants caused by strhenogenesis, even though Cd stress was applied to plants. The reason for this is that it may be originated from DELLA proteins that inhibit enzyme activity when $\mathrm{GA}_{3}$ is 
applied to plants at the time of stress. Enzyme activities and DELLA proteins should be looked for in order to be fully illuminated. In addition, after application of $\mathrm{GA}_{3}$ at the time of stress, the levels of organic acid in the cell should be monitored.

Acknowledgements. This work was supported by Research Fund of the Yuzuncu Yil University (Project No: 2010-FBE-YL159).

\section{REFERENCES}

[1] Achard, P., Cheng H., De Grauwe, L., Decat J., Schoutteten, H., Moritz T. (2006): Integration of Plant Responses to Environmentally Activated Phytohormonal Signals. Science 311: 91-94.

[2] Achard, P., Gong F., Cheminant S., Aliona M., Hedden P., Genschik P. (2008a): The Cold-Inducible CBF1 Factor-Dependent Signaling Pathway Modulates the Accumulation of the Growth-Repressing DELLA Proteins via Its Effect on Gibberellin Metabolism. The Plant Cell 20(8): 2117-2129.

[3] Achard, P., Renou, J. P., Berthome, R., Harberd, N. P., Genschik, P. (2008b): Plant DELLAs Restrain Growth and Promote Survival of Adversity by Reducing the Levels of Reactive Oxygen Species. - Current Biology 18: 656-660.

[4] Akman, Z. (2009): Effects of plant growth regulators on nutrient content of young wheat and barley plants under saline conditions. - Journal of Animal and Veterinary Advances 8(10): 2018-2021.

[5] Amal, M.E., Abdel-HamidHeba, I. M. (2014): The Effect Of The Exogenous Gibberellic Acıd On Two Salt Stressed Barley Cultıvars. - European Scientific Journal February 2014 edition 10:6 ISSN: $1857-7881$

[6] Ashraf, M., Karim, F., Rasul, E. (2001): Interactive effects of gibberellic acid (GA3) and salt stress on growth, ion accumulation and photosynthetic capacity of two spring wheat (Triticum aestivum L.) cultivars differing in salt tolerance. - Plant Growth Regulation 36(1):49-59.

[7] Bachir, L., Dango, M., Wu, F., Zhang, G., Wu, H. (2004): Genotypic Difference in Effect of Cadmium on Development and Mineral Concentrations of Cotton. - Communications in Soil Science and Plant Analysis 35(1-2): 285-299.

[8] Bertin, G., Averbeck, D. (2006): Cadmium; cellular effects, modifications of biomolecules, modulation of DNA repair and genotoxic consequences (areview). Biochimie 88: 1549-1559.

[9] Chandler, P.M., Mariol-Poll, A., Ellis, M., Gubler, F. (2002): Mutants at the Slenderl Locus of Barley cv Himalaya. - Molecular and Physiological Characterization, Plant Physiology 129(1): 181-190.

[10] Doğan, M., Saygideğer, S. (2009): Some Physiological and Morphological Effects on Ceratophyllum demersum L.of Cadmium. - Ecoloji 18(71): 57-64.

[11] El-Shahaby, O. A. (1992): Internal water status, endogenous levels of hormones, photosynthetic activity in well watered and previously water stressed Vigna sinensis plants under ABA effect. - Mans Sci Bull 19: 229-245.

[12] Foy, C.D., Chaney, R.L., White, M.C. (1978): The physiology of metal toxicity in plants. -Annu. Rev. Plant Physiol. 29: 511-566.

[13] Gür, N., Topdemir, A., Munzuroğlu, Ö., Çobanoğlu, D. (2004): Effects on Pollen Germination and Tube Growth. Of Heavy Metal Ions $(\mathrm{Cu}+2, \mathrm{~Pb}+2, \mathrm{Hg}+2, \mathrm{Cd}+2)$. Firat University Journal of Science and Mathematical Sciences 16(2): 177-182.

[14] Güven, O., Karadag, E., Saraydin, D. (1999): A review on the radiation synthesis of copolymeric hydrogels for adsorption and separation purposes. - Radiat. Phys. Chem. 56: 381-386. 
[15] Haktanır, K., Arcak, S. (1998): Environmental pollution. - Ankara University. Faculty of Agriculture Soil Department, Ankara Univ..Publication number: 1503, Lesson book:457, Ankara.

[16] Hoagland, D.R., Arnon, D.I. (1938): The water culture method for growing plants without soil. - Circ. Calif. Agr. Exp. Sta. pp. 347-461.

[17] Ikeda, A., Ueguchi- Tanaka, M., Sonoda, Y., Kitona, H., Koshioka, M., Futsuhara, Y., Matsuoka, M., Yamaguchia, J. (2001): Slender Rice, a Constitutive Gibberellin Response Mutant, Is Caused by a Null Mutation of the SLR1 Gene, an Ortholog of the HeightRegulating Gene GAI/RGA/RHT/D8. - The Plant Cell 13(5): 999-1010.

[18] Iqbal, M., Ashraf, M. (2013): Gibberellic acid mediated induction of salt tolerance in wheat plants: Growth, ionic partitioning, photosynthesis, yield and hormonal homeostasis. - Environmental and Experimental Botany 86: 76-85.

[19] John, R, Ahmad, P, Gadgil, K., Sharma, S. (2009): Cadmium and lead-induced changes in lipid peroxidation, antioxidative enzymes and metal accumulation in Brassica juncea L. at three different growth stages. - Archives of Agronomy and Soil Science 55(4): 395-405

[20] Kennedy, C.D., Gonsalves, F.A.N. (1987): The action of divalent zinc, cadmium, mercury, copper and lead on the trans-root potential and efflux of excised roots. - J.Exp. Bot. 38: 800-817.

[21] Lin, C.C., Kao, C.H. (1995): $\mathrm{NaCl}$ stress in rice seedlings: starch mobilization and the influence of gibberellic acid on seedling growth. - Bot Bull Acad Sin. 36: 169-173.

[22] Magome, H., Yamaguchi, S., Hanada, A., Kamiya, Y., Oda, K. (2008): The DDF1 transcriptional activator upregulates expression of a gibberellin-deactivating gene, GA2ox7, under high-salinity stress in Arabidopsis. - The plant journal 56(4): 613626.

[23] Marschner, H. (1986): Mineral Nutrition of Higher Plants. - Institute of Plant Nutrition University of Hohenheim Federal Republic of Germany. Academic Press.850p.

[24] Mohammed, A.M.A., Mohamed, H. I., Zaki, L.M., Mogazy, A.M. (2012): Pre-exposure to gamma rays alleviates the harmful effect of salinity on cowpea plants. - Journal of Stress Physiology and Biochemistry 8 (4): 199- 217.

[25] Moya, J.L., Ross, R., Picazo, I. (1993): Influence of cadmium and nickel on growth, net photosynthesis and carbohydrate distribution in rice plants. - Photosynthesis Research 36: $75-80$.

[26] Nagoor, S. (1997): A study of influence of cadmium and mercury on growth and protein metabolism in cowpea seedlings. - J. Phsiol. Research 10: 31-34.

[27] Ogawa, M., Kusano, T., Katsumi, Sano, H. (2000): Rice gibberellin-insensitive gene homolog, OsGAI, encodes a nuclear-localized protein capable of gene activation at transcriptional level. - Gene 245(1): 21-29.

[28] Pandit, B.R., Prasannakumar, P.G. (1999): Effect of Metals on Jowar (Sorghum bicolour L.) Seedling Growth-I, Germination, Seedling Growth and Absorption of Elements. Pollut. Res. 18: 459-466.

[29] Peng, J., Carol, P., Richard, D., King, K., Cowling R., Murphy, G., Harberd, N. (1997): The Arabidopsis GAI gene defines a signaling pathway that negatively regulates gibberellin responses. - Genes \& Dev. 11:3194-3205.

[30] Prasad, K.V.S.K., Paradha, S.P., Sharmila, P. (1999): Concerted action of antioxidant enzymes and curtailed growth under zinc toxicity in Brassica juncea. Environ. - Exp. Bot. 42: $1-10$

[31] Rascio, N., Vecchia, F.D., Ferretti, M., Merlo, L., Ghisi, R. (1993): Some effects of Cadmium on Maize Plants. - Arch. Environ. Contam. Toxicol. 25: 244-249.

[32] Rodríguez, A.A., Stella, A.M., Storni, M.M., Zulpa, G., Zaccaro, M.C. (2006): Effects of cyanobacterial extracellular products and gibberellic acidon salinity tolerance in Oryza sativa L. - Saline Systems 2:7.

[33] Salt, D., Price, R., Pickering, I., Raskin, I. (1995): Mechanisms of cadmium mobility and accumulation in Indian mustard. - Plant Physiol. 109: 1427-1433. 
[34] SAS-INSTITUE (1985): Sas/ State User's Guide 6.03 ed. SAS. Ins. Cary. N.C

[35] Schachtman, D., Lio, W. (1999): Molecular pieces to the puzzle of the interaction between potassium and sodium uptake in plants. - Trends in Plant Science 4: 281-287.

[36] Silverstone, A, Ciampaglio, Charles, Sun, T. P. (1998): The Arabidopsis RGA Gene Encodes a Transcriptional Regulator Repressing the Gibberellin Signal Transduction Pathway. - The Plant Cell 10 (2): 155-169.

[37] Stobart, R., Griffiths, F., Ameen-Bukhari, S. (1985): The effect of Cd+2 on the biosynthesis of chlorophyll in leaves of barley. - Physiol. Plant. 63: 293-298.

[38] Taleisnik, E., Peyran, G., Arias, C. (1997): Respose of Chloris gayana Cultivars to Salinity. 1. Germination and Early Vegetatif Growth. - Trop. Grassl. 31: 232-240.

[39] Tiryakioglu, M., Eker, S., Ozkutlu, F., Husted, S., Cakmak, I. (2006): Antioxidant defense system and cadmium uptake in barley genotypes differing in cadmium tolerance. - Journal of Trace Elements in Medicine and Biology 20(3): 181-189.

[40] Yasar, F., Uzal, O., Yeler, O. (2016): Effect on Plant Growth and Ionic Accumulation of Gibberellic Acid (GA3) to Eggplant Seedling under Salt Stress. - International Multidisciplinary Congress of Eurasia 2016, Odessa, Ukrayna, 11-13 July 2016, 2(1): 689-696.

[41] Zengin, K.F., Munzuroğlu, Ö. (2005): Effects on Chlorophyll and Carotenoid Amount of Bean seedling (Phaseolus vulgaris L.Strike) of Some Heavy Metals $(\mathrm{Ni}+2, \mathrm{Co}+2, \mathrm{Cr}+$ $3, \mathrm{Zn}+2)$. - Firat University Journal of Science and Engineering Sciences 17(1):164-172.

[42] Zhang, G.P., Fukami, M., Sekimoto, H. (2002): Influence of cadmium on mineral concentrations and yield components in wheat genotypes differing in Cd tolerance at seedling stage. - Field Crop Res. 77: 93-98. 